\title{
OBITUÁRIO DO PROF. DR. WINFRIED BRUGGER $(1950-2010)^{1}$
}

\author{
PETER HÄBERLE ${ }^{2}$
}

I

Como se haverá de formular um obituário de um cientista que foi arrancado subitamente da vida, de um professor de Direito do Estado que estava no auge de sua capacidade e do seu saber? Como se poderá fazer justiça à sua obra e à sua pessoa, como se irá avaliar a recepção de seus textos científicos, se ele faleceu aos 60 anos após uma grave e breve doença? Certamente existe, desde a Antiguidade, o cânone do necrológio, do discurso fúnebre, do obituário. Fazer isto cabe aos amigos e amigas que Winfried Brugger tinha particularmente nos EUA e no Brasil e aos alunos e alunas em Heidelberg que, desde o início, ele orientou e desafiou exemplarmente. $\mathrm{O}$ autor dessas linhas está ligado a Brugger, que partiu tão precocemente, principalmente através de uma simpatia comum pelo Brasil graças a várias visitas, colóquios dos quais participamos juntos (como em Porto Alegre, p. ex.) e à escolha de temas paralelos. Portanto, estas linhas são escritas dentro desse horizonte e se destinam exclusivamente à publicação na revista Direitos Fundamentais \& Justiça, editada pelo Prof. Ingo Wolfgang Sarlet, igualmente ligado pessoal e cientificamente ao falecido Prof. Brugger.

Pessoa e obra de um Professor de Direito do Estado não podem ser separadas em termos ideais. O ethos de sua ciência precisa ter, em sua atuação, um garante digno de crédito. Onde isso não for o caso - p. ex., no caso de autores que se comprometem com sistemas totalitários ou se deixam corromper redigindo abundantes pareceres para empresas - resta somente tristeza. Justamente a América Latina, que teve de suportar várias ditaduras militares e, nos anos que correm, vem superando de maneira exemplar o fardo que isso representa - p. ex. pela revogação de leis de anistia -, oferece abundante material para ilustrar essa tese. No caso de um artista, a pessoa e a obra podem ser divididas (basta pensar, p. ex., nos aspectos questionáveis da biografia de pessoas como P. Picasso ou B. Brecht), mas

\footnotetext{
${ }^{1}$ Agradecemos a Luis Sander pela disponibilização da tradução.

${ }^{2}$ Universidade de Bayreuth.
} 
não quando estamos falando de quem coloca a ciência a serviço do Estado Constitucional. Winfried Brugger foi um tal servo (do Estado Constitucional) desde o início.

\section{II}

Comecemos com a pessoa: nascido em 26 de fevereiro de 1950 em Würtemberg, Brugger estudou nas universidades de München e Tübingen. Seu orientador de doutorado foi Otto Bachof em Tübingen e o tema de sua tese foi "Ethos dos direitos humanos e política da responsabilidade: a contribuição de Max Weber para a análise e fundamentação dos direitos humanos" (1980). Mais tarde Brugger obteve o grau de Master of Laws em Berkeley. A tese com que se habilitou ao magistério universitário tratou do tema "Direitos fundamentais e jurisdição constitucional nos Estados Unidos" (1987). Desde então, ele é até hoje o melhor conhecedor do direito constitucional norte-americano na Alemanha. Isto se mostra, p. ex., no ensaio intitulado "Interpretação da constituição nos Estados Unidos" (JöR, v. 42, p. 571ss., 1994), publicado na coletânea "Democracia, liberdade, igualdade: estudos sobre o direito constitucional nos EUA" (2002), bem como na bem-sucedida obra de referência "Introdução ao direito público americano" (1993; 2. ed. 2001). Também existem numerosas recensões de Brugger sobre livros de Bruce Ackermann (1983/86) e de Ronald Dworkin (1985/87), mas também de obras do autor deste obituário (p. ex., "Problemas referentes à verdade no Estado constitucional", de 1993 [JZ, p. 1005s., 1995]).

Já cedo Winfried Brugger foi convidado a lecionar nas universidades de Mannheim e Heidelberg. Além disso, ele teve a sorte de poder pesquisar, na qualidade de "fellow", cerca de cinco anos no Instituto Max Weber em Erfurt, livre de obrigações burocráticas e de um excesso de atividades letivas. Nos últimos anos (2003-2008) também surgiram numerosas obras, que se devem igualmente à sua diligência, típica dos suébos (Schwaben). Sua bibliografia é riquíssima, pois ele domina todos os gêneros literários: da monografia a artigos científicos, do parecer sobre a publicação de livros e artigos à crítica de livros, da conferência à contribuição para o debate.

Além das muitas ocasiões em que atuou como professor visitante em renomadas Universidade Norte-Americanas, especialmente na Georgetown University, de Washington DC, ele também viajou várias vezes ao Brasil, com a colaboração do Prof. Ingo W. Sarlet, que pela primeira vez recebeu o Professor Brugger no Brasil e propiciou, em parceria com outros colegas (em especial com Gilmar Mendes, Marcos Maliska, Monia Hennig Leal, João Maurício Adeodato e Marcelo Galuppo), novas visitas e atividades conjuntas. Houve publicações suas em colaboração, entre outros, com o Prof. Sarlet (p. ex., JöR, v. 56, p. 613ss., 2008, sobre o constitucionalismo moderno a partir dos exemplos dos EUA, do Brasil e da Constituição alemã), e não poucos ensaios ou artigos seus foram traduzidos para o português, p. ex., artigo sobre o discurso do ódio na Alemanha e nos EUA, publicado tanto em 
coletânea sobre o tema da liberdade de comunicação (organizada por Ingo W. Sarlet, Livraria do Advogado Editora), quanto na Revista de Direito Público do Instituto Brasiliense de Direito Público. Da mesma forma merecem referência os artigos " $\mathrm{Da}$ Hostilidade Passando pelo Reconhecimento até a Identificação - Modelos de Estado e Igreja e sua Relação com a Liberdade Religiosa" (Revista Direitos Fundamentais \& Justiça $n^{\circ}$ 9, out./dez. 2009), "Separação, Igualdade, Aproximação, Três modelos da relação EstadoIgreja" (Revista Direitos Fundamentais \& Democracia no 7, Jan. 2010).

III

Desde o início, as pesquisas de Winfried Brugger tiveram um escopo muito amplo, incluindo a Filosofia do Direito (p. ex., "Traços básicos da filosofia kantiana do direito", JZ, p. 893ss., 1991) e a sociologia, ao se dedicar ao "comunitarismo liberal" ("O comunitarismo como teoria constitucional da Lei Fundamental alemã", AöR, v. 123, p. 337ss., 1998). Uma expressão dessa pesquisa profundamente interdisciplinar é, p. ex., a figura da "Cruz antropológica da decisão" (2005, 2. ed. 2008). A dignidade humana e a imagem do ser humano (cf. seu livro "Dignidade humana, direitos humanos, direitos fundamentais", de 1997), o fundamento e os limites da liberdade de expressão, a relação entre liberdade e segurança bem como o bem comum ("Bem comum como concepção integrativa de segurança jurídica, legitimidade e conformidade a fins", in: id., S. Kirste e M. Anderheiden [eds.], "O bem comum na Alemanha, na Europa e no mundo" [2002]) se tornaram, assim, temas repetidamente abordados em sua atividade intelectual. Ele também se destacou como editor de coletâneas interdisciplinares, entre as quais cito especialmente o volume intitulado "A legitimação da Constituição alemã na perspectiva da filosofia do direito e da teoria da sociedade" (1996; cf. minha resenha: AöR, v. 123, p. 476ss., 1998). Através de seu jeito de ser amistoso e equilibrado, conseguiu colocar em diálogo muitos colegas com argumentos divergentes. Entre suas últimas publicações se encontra o ensaio "Separação, igualdade, proximidade: três modelos da relação entre Estado e Igreja" (in: A. Reuter et al. [ed.], "Conflitos religiosos no Estado constitucional", 2010, p. 119ss.). Lembro também sua grande conferência no encontro de professores de Direito do Estado em Hamburgo ("Garantias da liberdade e da segurança à luz de diversas compreensões de Estado e constituição", VVDStRL, v. 63, p. 101ss., 2004).

Brugger se tornou conhecido na opinião pública alemã através de suas teses extremamente controversas sobre a "tortura salvadora", como dá conta o artigo "Pode o Estado torturar em casos excepcionais?", in: Der Staat, v. 35, p. 67ss., 1996). Contrariando a opinião dominante, ele relativizou a garantia da dignidade humana em casos de extrema excepcionalidade, embora essa garantia seja, ao meu ver, uma premissa antropológico-cultural do Estado constitucional. Entretanto, continua sendo mérito de Brugger ter provocado a discussão de maneira incisiva e de tê-lo introduzido na consciência geral. 
O que permanece? Esta pergunta ainda não pode ser respondida de forma precisa. De modo geral, porém, pode-se dizer que na história da Teoria do Direito do Estado na Alemanha após 1945, cujos pioneiros foram pessoas como Günter Dürig, Otto Bachof e Konrad Hesse, Brugger ocupou ou adquirirá um lugar de destaque na segunda geração. Ele associou de forma exemplar a doutrina do Direito do Estado e a Filosofia do Direito; como quase único autor alemão, abordou de forma comparativa, com conhecimento de causa, temas norte-americanos e brasileiros; enriqueceu a literatura sobre os direitos humanos e cultivou um promissor grupo de discípulos que deverão levar seu legado adiante. No Brasil, também graças à sua personalidade aberta, gentileza e simpatia, ele não será esquecido. 